\title{
Particle fluxes over a Mediterranean seagrass bed: a one year case study
}

\author{
Patrick Dauby ${ }^{1, *}$, Antony J. Bale ${ }^{2}$, Nick Bloomer ${ }^{2}$, Christine Canon $^{1}$, \\ Roger D. Ling ${ }^{2}$, Alain Norro ${ }^{1}$, Jane E. Robertson ${ }^{2,3}$, Alain Simon ${ }^{4}$, \\ Jean-Marie Théate ${ }^{1}$, Andrew J. Watson ${ }^{2}$, Michel Frankignoulle ${ }^{1}$ \\ ${ }^{1}$ Laboratoire d'Océanologie, Université de Liège, B6-Sart Tilman, B-4000 Liège, Belgium \\ ${ }^{2}$ Plymouth Marine Laboratory, Prospect Place, West Hoe, Plymouth PL1 3DH, United Kingdom \\ ${ }^{3}$ Department of Earth Sciences, Cardiff University, PO Box 914, Cardiff CF1 3YE, Wales, United Kingdom \\ ${ }^{4}$ Laboratoire de Morphologie, Systématique \& Ecologie Animales, Université de Liège, 22, Quai Van Beneden, \\ B-4020 Liège, Belgium
}

\begin{abstract}
A sediment trap experiment was carried out in the Bay of Calvi (Corsica, France) over a Posidonia oceanica seagrass bed, at a depth of $36 \mathrm{~m}$. The traps collected 44 samples over a complete annual cycle and allowed a rough partition between 'sinking' and 'resuspended' matter. The measured annual flux of particulate matter amounted to $1.3 \mathrm{~kg} \mathrm{~m}^{-2}$, of which about $70 \%$ arose from sediment resuspension, this process being particularly enhanced during northerly gales. Resuspended material consisted mainly of seagrass-derived detritus, as evidenced by SEM photomicrographs. Chemical analyses of trapped material showed seasonal variations in inorganic carbon content, organic $\mathrm{C} / \mathrm{N}$ ratio and $\delta^{13} \mathrm{C}$. Benthic signature $\left(\mathrm{C}_{\text {norg }}{ }^{-}, \mathrm{C}_{\text {org- }}\right.$ and ${ }^{13} \mathrm{C}$-enriched Posidonia-derived matter $)$ was emphasized when resuspension occurred, while planktonic features $\left(\mathrm{N}\right.$ - and ${ }^{12} \mathrm{C}$-enriched matter) prevailed during bloom conditions.
\end{abstract}

KEY WORDS: Suspended matter - Seagrass Detritus - Plankton-Sediment trap

\section{INTRODUCTION}

In almost all temperate and tropical coastal areas, seagrasses constitute a unique kind of ecosystem in which the biogeochemical cycling of major elements is important. Research into seagrass ecosystems, mainly under the instigation of the IGBP (McRoy \& Helfferich 1977, Phillips \& McRoy 1980, Larkum et al. 1989), has been extensive. As a matter of fact, seagrasses form - with coral reefs - the largest concentrations of marine primary producers in the infralittoral zone, and thus could act as important sinks for atmospheric $\mathrm{CO}_{2}$ (Smith 1981, Frankignoulle \& Gattuso 1993). They also shelter diverse communities of organisms for which they represent substratum, nursery and food source. Finally, they play a major role in

\footnotetext{
•E-mail: pdauby@vm1.ulg.ac.be
}

the trapping and stabilization of sediments in shallow waters.

In the Mediterranean Sea, the seagrass settlement is largely dominated by Posidonia oceanica, a robust species with a pronounced annual vegetation cycle: despite leaf fall taking place throughout the year, its rhythm shows considerable acceleration at the end of summer and in autumn (Caye 1982, Pergent \& Pergent-Martini 1990). This species is also characterized by prevalence of the asexual mode of reproduction, propagation being achieved via a dense web of socalled plagiotropic rhizomes. Another kind of rhizome (orthotropic) growing vertically prevents the burial of the shoots. This rhizome system is responsible for the trapping of large amounts of sedimentary matter with which it forms compact beds ('mattes') that can reach several metres in height. Most of the organic matter accumulated this way is therefore lost for the ecosystem epifauna, and ${ }^{14} \mathrm{C}$ measurements have allowed 
such fossilized accumulations to be dated up to $4500 \mathrm{yr}$ B.P. (Boudouresque et al. 1980).

The accumulation rate of sedimentary matter in Mediterranean Posidonia oceanica beds has, until now, been estimated only by indirect methods, using, e.g., isotopic dating of cored material (Boudouresque et al. 1980, Thommeret 1985) or lepidochronology (Pergent \& Pergent-Martini 1990). These techniques yield net sedimentation rates over long time periods but do not provide any information about the actual amounts of matter reaching the sea floor or its origins. This paper presents an original set of data obtained during 1 complete annual cycle in the Bay of Calvi (Corsica, France) utilizing a sequential sediment trap. A total of 44 samples were collected at $8 \mathrm{~d}$ intervals. With this data, we analysed the total annual settling flux, distinguishing between sinking and autochthonous resuspended material, and obtained information regarding its origin using inorganic and organic carbon, nitrogen, and stable isotope measurements.

\section{MATERIAL AND METHODS}

The sediment trap was deployed in the Bay of Calvi, northwestern Corsica $\left(42^{\circ} 35^{\prime} \mathrm{N}, 8^{\circ} 45^{\prime} \mathrm{E}\right)$. This semienclosed bay (Fig. 1) is open to the north and has an
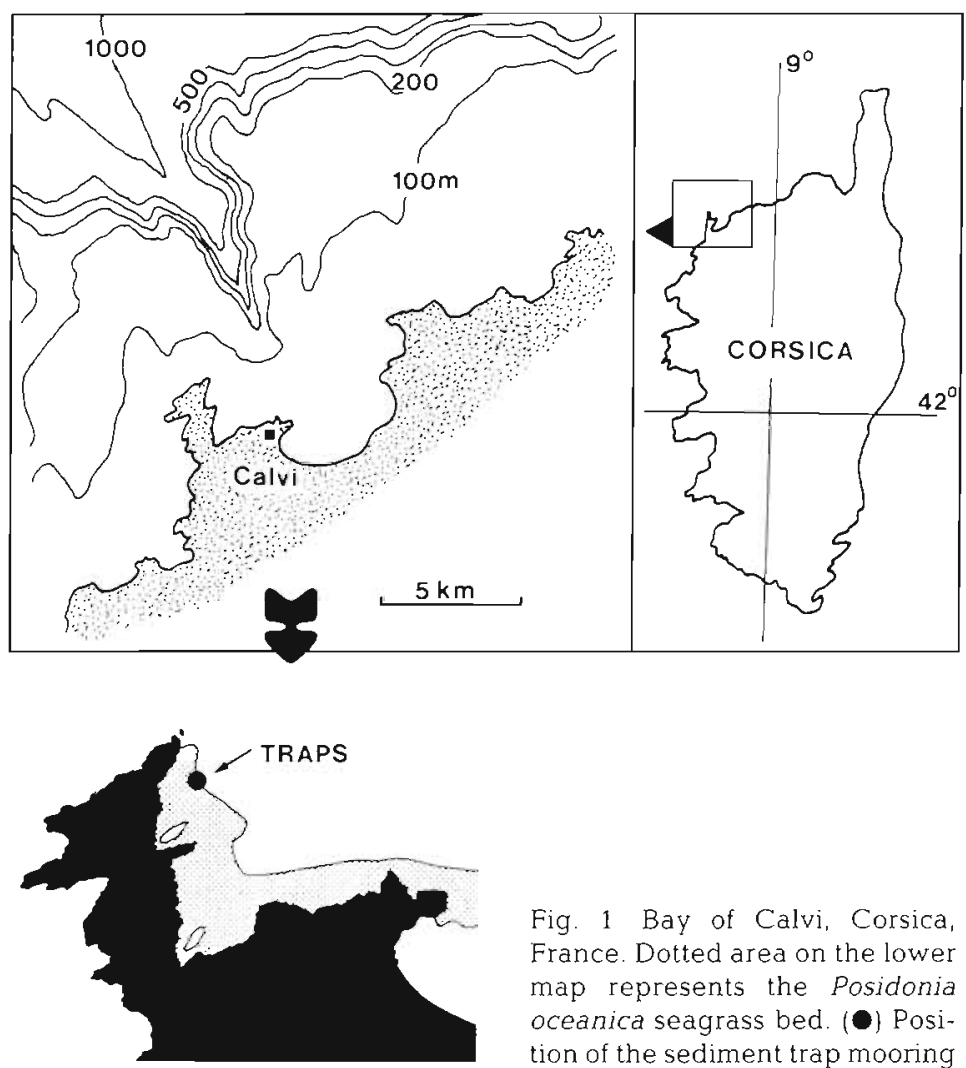

Fig. 1 Bay of Calvi, Corsica, France Dotted area on the lower map represents the Posidonia oceanica seagrass bed. (O) Position of the sediment trap mooring area of about $10 \mathrm{~km}^{2}$. Water depths increase progressively (slope: $2 \%$ ) from southwest to northeast, reaching $100 \mathrm{~m}$. The annual pattern of surface water temperatures has a classical summer maximum (about $26^{\circ} \mathrm{C}$ in August) and a winter minimum $\left(13^{\circ} \mathrm{C}\right.$ in March); the water column is stratified from May to September, with a thermocline which varies from 10 to $50 \mathrm{~m}$ depth according to wind stress. The salinity (38) does not change significantly throughout the year. Currents are weak $\left(\leq 5 \mathrm{~cm} \mathrm{~s}^{-1}\right)$ and circulation consists mainly of a local residual gyre. Winds are mainly from the 200-250 (Libeccio) and 320-60 (Mistral and Tramontane) sectors. Southerly winds, owing to the geographical situation of the Bay, only slightly affect the local sea surface (see also Fig. 5). Data are from the present work, and from Burhenne (1981), Bay (1984) and Dauby (1985).

The Bay of Calvi is characterized by the presence of a wide and well-preserved Posidonia oceanica seagrass bed which covers the seafloor from subsurface to $38 \mathrm{~m}$ depth (i.e. about half the total surface of the Bay). The Bay waters are oligotrophic, and a significant plankton bloom occurs in the early spring as a result of both winter mixing of water masses and increasing of solar radiation.

The trap experiment was conducted using the 'PML Sequential Sediment Trap' recently developed by the Plymouth Marine Laboratory (Bale 1995). This device consists of 4 PVC cylinders [cross-sectional exposed area $194 \mathrm{~cm}^{2}$; aspect ratio (height/diameter) $>5$ ] mounted on a stainless steel frame. Carousels mounted underneath 2 of the tubes are driven by a motor, allowing the sequential collection at preset intervals of 11 individual samples per immersion (sequential sediment trap, SST). The other 2 tubes collected a single pair of samples and thus acted as integrators throughout the whole immersion period (integrating sediment trap, IST). One cylinder of each type was fitted with a conical cap attached a few centimetres above the tube rim. This hindered sinking particles from entering the trap but allowed the collection of resuspended particles (SST ${ }^{*}$ and IST ${ }^{*}$ ). The 4 cylinders were fitted with flasks poisoned with $0.1 \%$ mercury chloride in order to minimize microbial mineralisation of organic material. The other 2 cylinders (SST and IST) were covered with a net (about $1.5 \mathrm{~cm}$ mesh) to avoid penetration by very large detritus and, above all, octopuses, which are common in the area.

The traps were deployed on the sea floor within the seagrass bed by divers at a depth 
of $36 \mathrm{~m}$, which was close to the lower limit of the bed. At this depth, Posidonia oceanica density averages 50 shoots $\mathrm{m}^{-2}$ (S. Gobert, S. Havelange, S. Belkhiria, P. Dauby, M. Soullard \& J.-M. Bouquegneau unpubl.) with patchy coverage. It reaches more than 400 shoots $\mathrm{m}^{-2}$ at $10 \mathrm{~m}$ and about 170 shoots $\mathrm{m}^{-2}$ at $30 \mathrm{~m}$ depth (Soullard et al. 1994). A total of 4 deployments were carried out (June 6 to August 26, 1990; September 5 to November 25, 1990; December 7, 1990 to March 27. 1991: April 3 to May 30, 1991), resulting in $44(4 \times 11)$ sequential samples, each one lasting about $1 \mathrm{wk}$. The precise intervals were respectively $7.4,7.4,10$ and 5.2 d. For each deployment, the motor driving the carousels was preset to start collecting $12 \mathrm{~h}$ after deployment in order to avoid trapping sediments mobilized by the divers.

Each sample was analyzed for total matter, total inorganic carbon content (TIC), organic C/ $\mathrm{N}$ ratio, and organic $\delta^{13} \mathrm{C}$. TIC was determined by differential weighing after acidification with acetic acid (HAc at $70^{\circ} \mathrm{C}$ was run through the sample till no more bubbling occurred). $\mathrm{C} / \mathrm{N}$ ratios were measured using a Carlo Erba Elemental Analyzer (model NA 1500). For $\delta^{13} \mathrm{C}$, carbonate-free material was first combusted with copper oxide wire in vacuum-sealed quartz tubes, then analyzed with a Varian MAT CH5 IR-MS; values are reported relative to $\mathrm{PDB}$ standard as

$$
\delta^{13} \mathrm{C}=\left[\left(R_{\text {sample }} / R_{\text {standard }}\right)-1\right] \times 1000
$$

where $R$ is the ${ }^{1.3} \mathrm{C}:{ }^{12} \mathrm{C}$ ratio.

A subsample of $0.5 \mathrm{ml}$ was taken from each fresh sample and immediately fixed with $10 \%$ glutaralde- hyde in seawater for scanning electron microscope (SEM) imagery.

Subsurface horizontal plankton net hauls (WP2 net; $180 \mu \mathrm{m}$ mesh size; 5 min sampling at half a knot speed) were performed daily from February 7 to March 29, 1991 , in order to relate plankton biomass to the mass flux observed in the traps.

An Aanderaa current meter (model RCM7) was deployed near the traps from December 1990 until the end of the experiment in order to record variations in near-bed current direction and velocity.

\section{RESULTS AND DISCUSSION}

\section{Year variations in the bulk of trapped matter}

The amount of matter collected in the SST is relatively low from the beginning of May to mid-October (Fig. 2), averaging $325 \mathrm{mg}$ dry wt $\mathrm{m}^{-2} \mathrm{~d}^{-1}$, but increases significantly in autumn, reaching a maximum in December of about $13.5 \mathrm{~g} \mathrm{~m}^{-2} \mathrm{~d}^{-1}$. Another maximum is observed on January 11 (see Fig. 2), but corresponds to disturbances brought about by divers visiting the trap site. During winter and early spring, several peaks of trapped matter are also observed, ranging from 6 to $10 \mathrm{~g} \mathrm{~m}^{-2} \mathrm{~d}^{-1}$. Both the relative peaks of December 12 and April 6 immediately follow a new trap deployment, and we suggest that the amount of matter collected might have been enhanced by diver activity in the vicinity of the trapping device, despite the fact that sample collection was deferred by $12 \mathrm{~h}$.
Fig. 2. Annual evolution of the amounts of total matter trapped in open sediment traps (SST; see 'Materials and methods') in the Bay of Calvi. Dashed arrows indicate the trap deployments. The column marked with an asterisk (Jan 11) could correspond to an artifact (see 'Results and discussion')

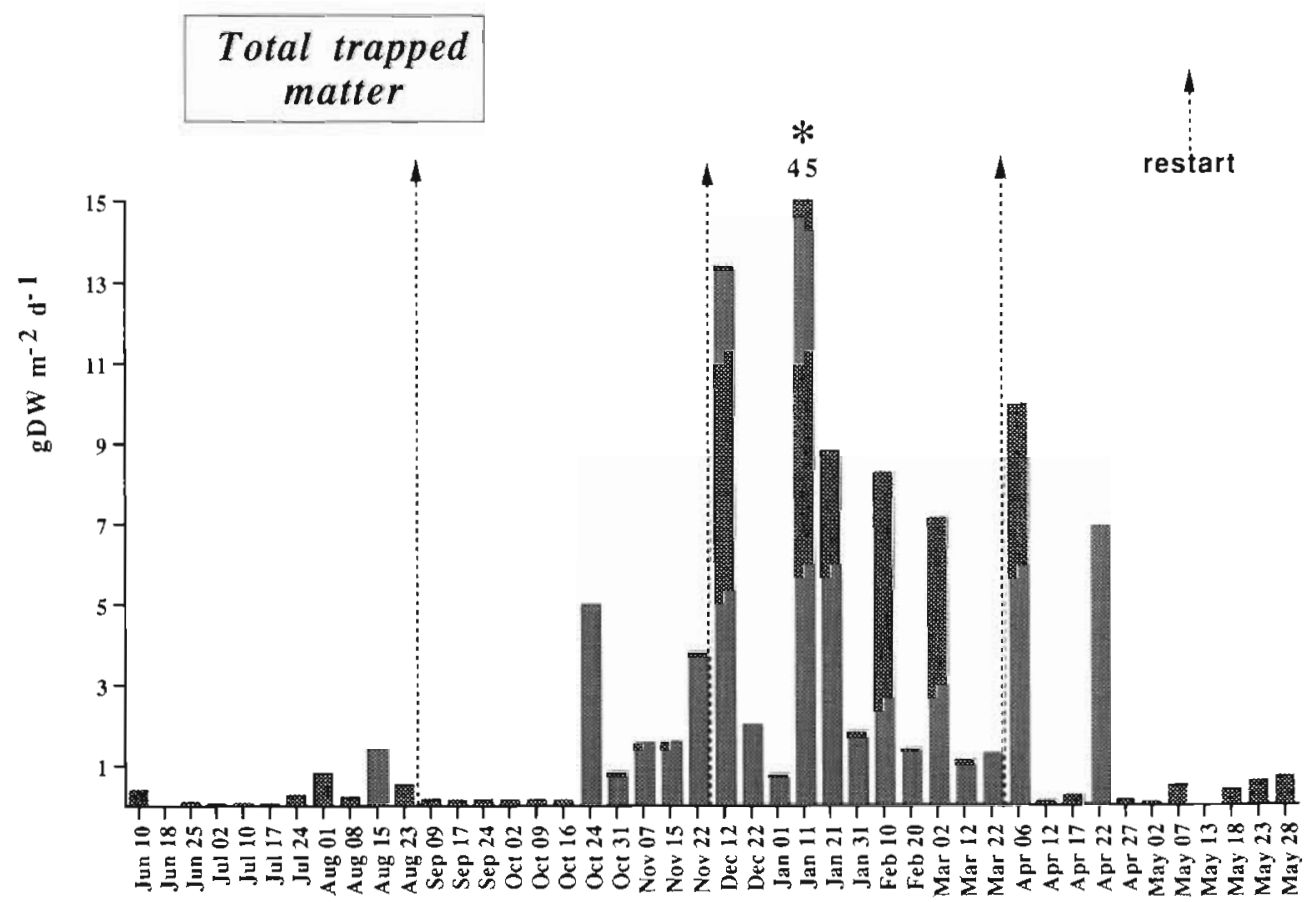




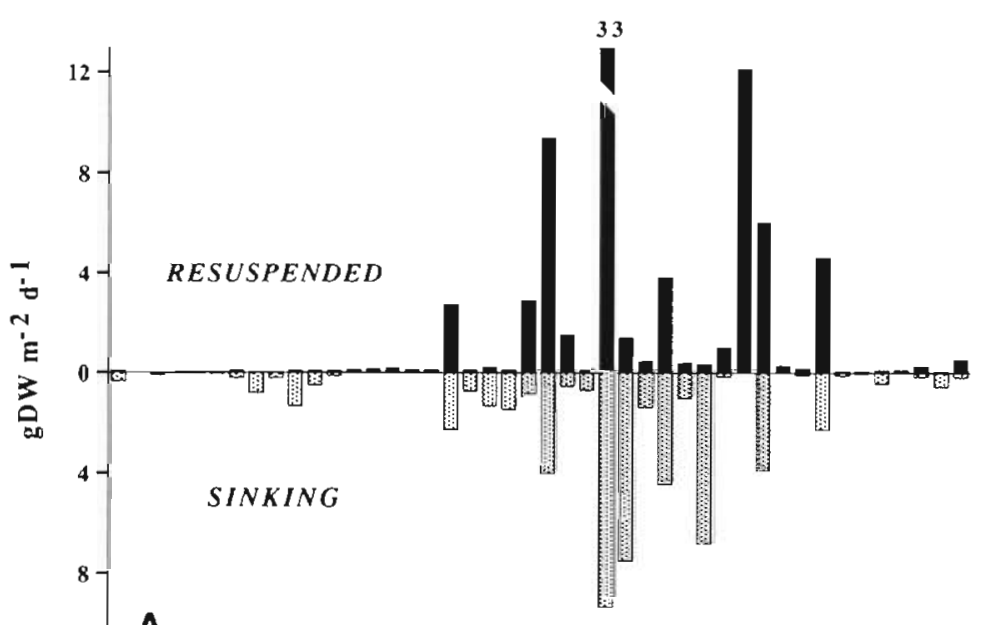

A

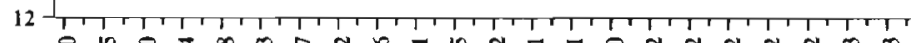

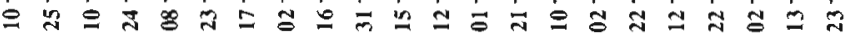

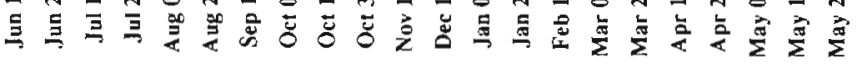

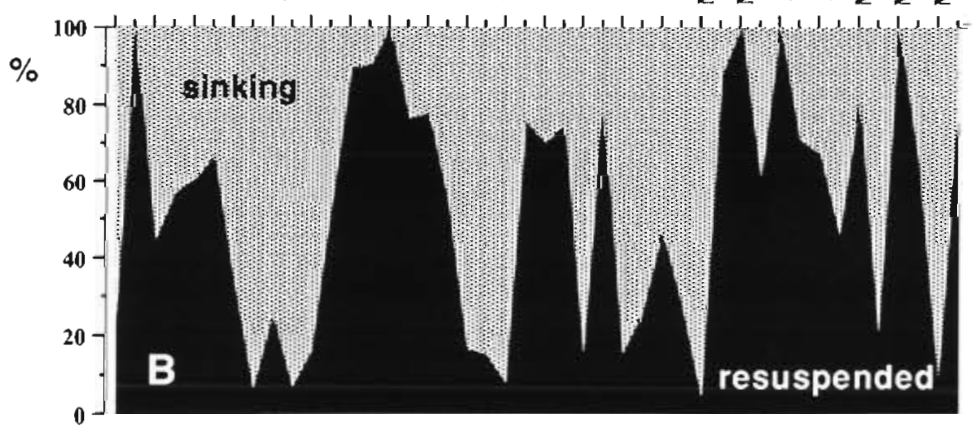

Fig. 3. Annual evolution of the (A) amounts and (B) relative proportions of 'resuspended' and 'sinking' matter collected in the traps

with peaks in the 'resuspended' material. Similar wind/current/rate of resuspension relationships were also observed by Hedges et al. (1988b) in Dabob Bay and by Sherwood et al. (1994) during the recent STRESS experiment on the U.S. Pacific coast. Moreover, the SEM imagery shows that heavy winter and spring samples contain a large amount of Posidonia oceanica seagrass waste (pieces of senescent leaves and epiphytes), indicating that resuspension processes were important. The total matter trapped over the year in $\mathrm{SST}^{*}$ represents $917 \mathrm{~g} \mathrm{~m}^{-2}$, i.e. a mean value of $2.55 \mathrm{~g}$ $\mathrm{m}^{-2} \mathrm{~d}^{-1}$, which corresponds to $68 \%$ of the total matter trapped in SST.

The sampling performance of SST and $\mathrm{SST}^{\cdot}$ traps can be evaluated by comparing the amounts of matter collected by each system or by comparing the summed amounts collected by SST/SST against amounts collected by IST/IST ${ }^{*}$ integrators. The amounts collected in 'topped' traps (SS $\Gamma^{*}$ ) should always be lower than in the SST, as the former theoretically do not sample sinking matter. This is unfortunately not always the case, as 4 of the $44 \mathrm{SST}^{\text {* samples were }}$ heavier than corresponding SST samples (2 October, +25\%; 22 March, +843\%; 12 April, $+146 \% ; 13$ May, $+266 \%$ ). These discrepancies could reflect a snaring effect of SST * cone caps on resuspended matter, or maybe a 'cryptic swimmer' problem

The total mass of material trapped over the year in the SST was $1341 \mathrm{~g} \mathrm{~m}^{-2}$, i.e. a mean value of $3.73 \mathrm{~g} \mathrm{~m}^{-2}$ $\mathrm{d}^{-1}$.

Measurement of the amount of matter collected in the SST ${ }^{*}$ theoretically allows the total trapped matter to be partitioned between material which is settling from the water column and material resuspended from bottom sediments (the former fraction being calculated as the differential matter: Mass $_{\mathrm{SST}}-$ Mass $_{\mathrm{SST}}$ ). Fig. 3 shows the annual variations in the respective amounts of 'sinking' and 'resuspended' matter and the evolution of the relative percentages of both matter sources. Several peaks of the 2 sources occur during the year, mainly focused in winter and spring.

Peaks of 'resuspended' material are probably related to storms which induce turbulence in the bottom layer and cause sediment resuspension. Analysis of direction and velocity patterns of both surface wind and bottom water current (Fig. 4) shows that northerly gales induce increased currents (up to $10 \mathrm{~cm} \mathrm{~s}^{-1}$, towards NE). The northerly winds and concomitant current peaks also correspond (except in mid-July)
(Michaels et al. 1990). On the other hand, the summed amounts of matter collected by SST/SST * during the 11 intervals of an array should be of the same order of magnitude as the amounts sampled by IST/IST ${ }^{*}$ integrators during the same trap deployment. This assumption is verified for almost all the sampling arrays (Table 1), but, as a general trend, integrators apparently collect less matter ( $26 \%$ on the average) than sequential traps do. This could be explained by the fact that the integrators remain open for nearly $3 \mathrm{mo}$, and thus are more susceptible to bacterial degradation and, hence, grazing pressure of miscellaneous organisms.

The largest amounts of differential ('sinking') matter were observed from October to April, with maximum values from mid-January to early March. These maxima (up to $9 \mathrm{~g} \mathrm{~m}^{-2} \mathrm{~d}^{-1}$ ) coincide with winter peaks in phytoplankton (mainly diatoms and nanoplankton) biomass which averaged $0.7 \mathrm{mg}$ chlorophyll $\mathrm{m}^{-3}$ during the bloom (Dauby 1985) and can reach up to $1.5 \mathrm{mg}$ $\mathrm{m}^{-3}$ (Brohée et al. 1989). This equates to 3 to $5.5 \mathrm{~g}$ dry wt $\mathrm{m}^{-2}$ on a $36 \mathrm{~m}$ depth water column. Eppley et al. 

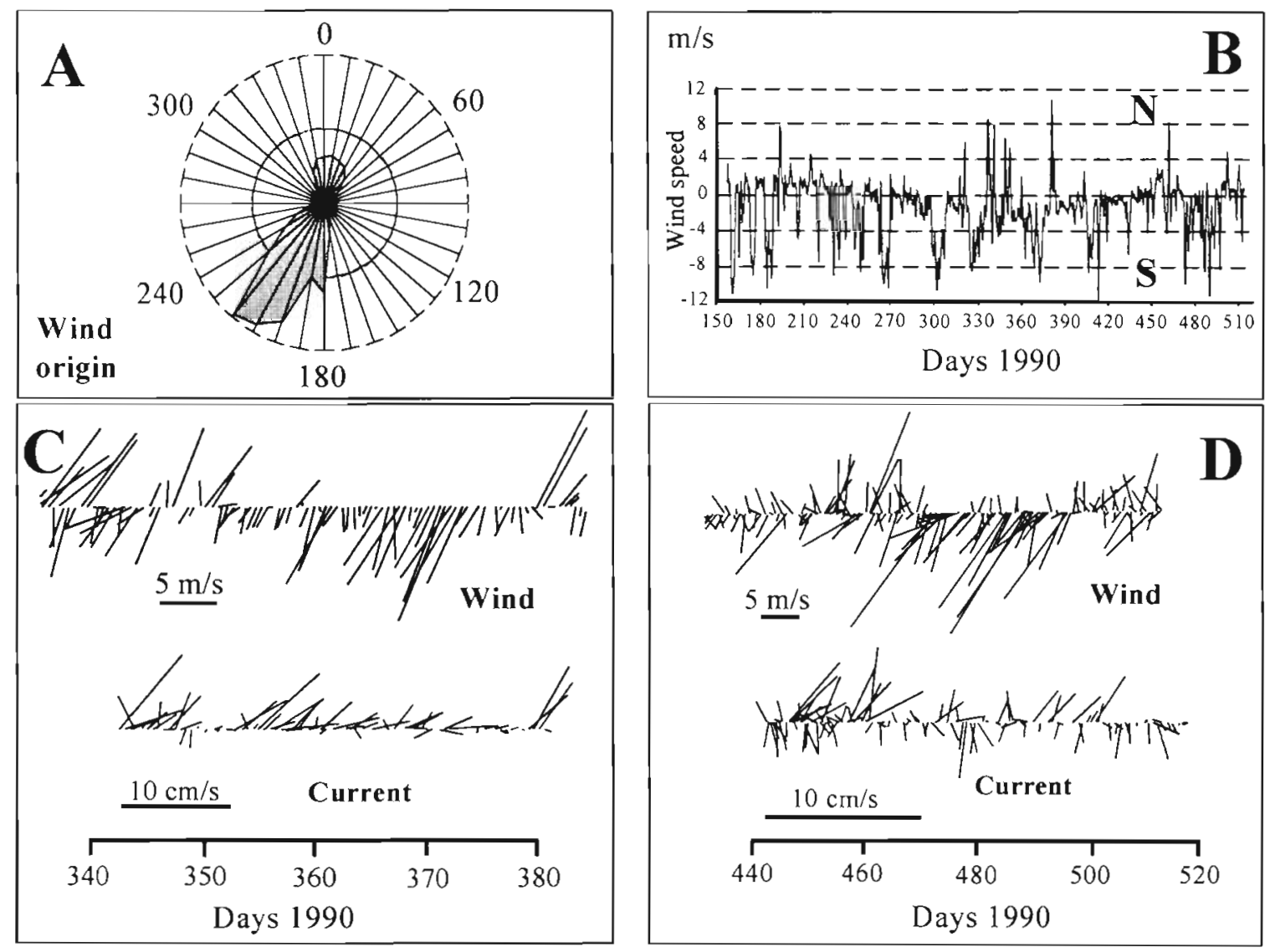

Fig. 4. Wind and bottom currents during the 1990-1991 sediment trap experiment in the Bay of Calvi: (A) sectorial (10 $\left.{ }^{\circ}\right)$ frequency distribution of wind origins; $(B)$ wind speed magnitude $\left(\mathrm{m} \mathrm{s}^{-1}\right.$ ) (positive and negative values respectively for $271 \rightarrow 90^{\circ}$ and $91 \rightarrow 270^{\circ}$ winds); and time series of wind and bottom current vectors for (C) December to January (days 1990) and (D) March to May (days 1990)

(1983) have shown that the residence time of particulate organic carbon $\left(\tau_{\mathrm{POC}}\right)$ in the ocean surface layer decreased to a few days during periods of enhanced primary production; such short $\tau_{\text {POC }}$ could explain the observed correlation between plankton blooms and trapped matter. For February and March 1991, a corre-

Table 1. Comparisons between total amounts of matter collected during the 4 deployments of the Sequential Sediment Trap in the Bay of Calvi (in g dry wt $\operatorname{trap}^{-1}$ array $^{-1}$ ). ESST and $\Sigma S S T$ " are the summed amounts for the 11 sequential samples of each array (respectively 'open' and 'capped' traps), IST and IST ${ }^{*}$ are the corresponding amounts for the integrator samples (see 'Materials and methods'). Diff: differences

\begin{tabular}{|lrrcrrr|}
\hline Array & ESST & IST & Diff $(\%)$ & ESST. & IST. & Diff (\%) \\
\hline Jun 6-Aug 26 & 0.703 & 0.560 & -20 & 0.129 & 0.305 & +136 \\
Sep 5-Nov 25 & 2.307 & 1.715 & -26 & 1.168 & 0.933 & -20 \\
Dec 7-Mar 27 & 20.638 & 14.603 & -29 & 15.006 & 12.033 & -20 \\
Apr 3-May 30 & 2.330 & 2.327 & - & 1.467 & 1.945 & +33 \\
Year total $\left(\mathrm{g} \mathrm{m}^{-2}\right)$ & 1341 & 991 & -26 & 917 & 786 & -14 \\
\hline
\end{tabular}

lation is observed between the biomass of zooplankton caught in nets and the mass of 'sinking' trapped matter (Fig. 5), despite the fact that neither zooplankters nor their fecal pellets appear in larger amounts in corresponding trap samples. As record time base differs for both parameters (daily vs weekly sampling frequency), a correlation coefficient can hardly be calculated; nevertheless, its value is 0.47 if using summed or averaged zooplankton biomasses. Other peaks of sinking mass, though less important, are observed in May and during the summer, and probably correspond to small blooms of silicoflagellates and dinoflagellates that occur regularly in the Bay of Calvi (about $0.2 \mathrm{mg}$ chlorophyll $\mathrm{m}^{-3}, \sim 0.7 \mathrm{~g}$ dry wt $\mathrm{m}^{-2}$; Licot 1985).

We suggest that the so-called 'swimmer problem' (Knauer et al. 1984, Harbison \& Gilmer 1986, Lee et al. 1988, Heussner et al. 1990, Michaels et al. 1990) was not 


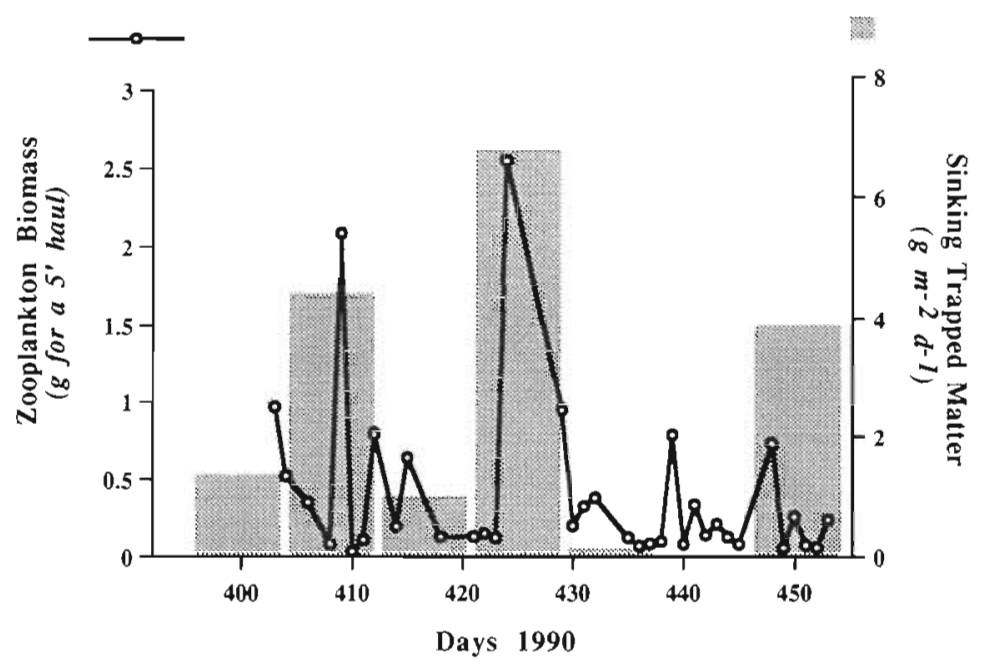

Fig. 5. Variations of zooplankton biomass (-o-) and of 'sinking' trapped matter mass (bars) for the period February 7 to March 29, 1991. (expressed as days 1990). Note the difference in scales

important during our experiment. Large swimmers like mysids or other crustaceans were easily removed from the samples. Small copepods (which at Calvi represent typically more than $95 \%$ of the zooplankton bulk; Dauby 1985) and their fecal pellets were scarce on the filters examined by light and SEM microscopy, and thus barely influenced mass estimations and chemical analyses. Other zooplankters like gelatinous zooplankters (siphonophores or salps) or larvaceans are occasionally found in Calvi's waters but only during warmer months; their influence on trapped material composition could thus be neglected, although it was noticed that e.g. appendicularian 'houses' could drastically bias results of traps deployed in shallow waters (Michaels et al. 1990, in the North Pacific).

On the other hand, an estimation of the efficiency ratio of our trapping system is not possible, with no current technique being sufficiently accurate to determine it. In a recent paper, Buesseler (1991), using a ${ }^{234}$ 'Th-based scavenging model, says '... we may not be able to give a definitive answer to the question posed in the title [Do upper-ocean sediment traps provide an accurate record of particle flux ?] ... suggests that the answer is not likely to be in the affirmative' and shows that discrepancies between measured and actual fluxes in shallow traps can differ by a factor of \pm 3 to 10 . Moreover, traps deployed in shallow waters are subjected to local hydrodynamic disturbances, and, as Monaco et al. (1990) say, '[measured] fluxes are only indicative, and .. primarily constitute a record of stormy events'. It has also been shown that the local horizontal current velocity (the Reynolds number) has a large influence on the settling of particles and, of course, their penetration efficiency into traps (Hargrave \& Burns 1979, Gardner et al. 1983, Gardner 1985). No tilt effect can be evoked in this experiment, as our trap was mounted vertically on the seafloor. Keeping these critical remarks in mind, we believe that traps are the best system to record sedimentation events in a coastal area, such as the Calvi Bay, where the usual current velocities are very low ( $\leqslant 10 \mathrm{~cm} \mathrm{~s}^{-1}$ ).

The relevance of our trap measurements to other sites in the Bay of Calvi could be questioned, mainly because of the anisotropic feature of hydrodynamics. The horizontal variability (i.e. following isobaths) can, however, be assumed to be trifling, as at Calvi the general water circulation pattern consists of a large counterclockwise gyre parallel to the coastline. The vertical variability (i.e. following the bottom slope) is obviously not trivial, as the effect of stormy events progressively decreases with depth. In situ observations, made while diving hundreds of times within the Posidonia oceanica bed during bad weather conditions, have shown that the behaviour of the bottom layer is roughly similar in the whole bed below $15 \mathrm{~m}$ depth. Closer to the surface, large debris (pieces of litter or of algae) are frequently mobilized by storms, with the result that the 'resuspended' fraction increases compared to what occurs at, e.g., the study site.

\section{Inorganic carbon content}

The total inorganic carbon content (TIC) of trapped material is rather high throughout the year, usually ranging from 12 to $50 \%$, with an average of 33 and $28 \%$, respectively, for SST and SST * samples. A correlation $(r=0.69, p=0.0001)$ is observed between $\mathrm{TIC}_{\mathrm{SST}}$ and $\mathrm{TIC}_{\text {SST }}$. contents (Fig 6A), with a slope of 0.64 , suggesting that the 'resuspended' matter is generally carbonate-lighter than the 'sinking' fraction. Some $\mathrm{TIC}_{\mathrm{SST}} / \mathrm{TIC}_{\mathrm{SST}}$. values (for June 10, July 2, August 1 , May 28; see Fig. 6A) appear to be anomalous, as they correspond neither to any occurrence of calcareous macroplankters (as pteropods) nor to any bottom event that could induce resuspension of $\mathrm{CaCO}_{3}$-rich material.

The TIC content of 'sinking' matter can be estimated, knowing $\mathrm{TIC}_{S S \mathrm{~T}}$ and $\mathrm{TIC}_{\text {SST }}$. contents, as

$$
\mathrm{TIC}_{\mathrm{Sink}}=\left[\mathrm{TIC}_{\mathrm{SST}}-\frac{\mathrm{TIC}_{\mathrm{SST}} \cdot \times M_{\mathrm{SST}}}{M_{\mathrm{SST}}}\right] \times \frac{M_{\mathrm{SST}}}{M_{\mathrm{SST}}-M_{\mathrm{SST}}}
$$


where TIC is expressed in $\%$, and $M$ is sample mass The annual evolution of TIC in both 'sinking' and 'resuspended' matter is shown in Fig. 6B. If we except the artificial peaks yielded by the calculation formula (when, e.g., $M_{S S T}<M_{S S T}$ ), it appears that $\mathrm{TIC}_{\text {Sink }}$ is almost constant (about $40 \%$ ) in July through August and from mid-October to the end of winter. From late August to mid-October, the TIC percentage decreases sharply; this period coincides with the maximum deepening of the thermocline, and thus possibly with a nutrient depletion - and concurrently with limited primary production - in the water column over the trap. During the spring, $\mathrm{TIC}_{\text {Sink }}$ content also decreases and thus is attributed to the conspicuous prevalence of diatoms in phytoplankton, the test of which is carbonate-free.

The annual evolution of TIC in 'resuspended' matter shows less variation. Values range from $20 \%$ during warm months to 35 to $43 \%$ during fall and winter, which is mostly a result of storms which cause resuspension of bed sediments (the carbonate content of which can range from 80 to $98 \%$; Burhenne 1981) and $\mathrm{CaCO}_{3}-$ rich dead pieces of seagrasses epiphytized by calcareous algae.

The relatively high amounts of TIC measured in the samples (compared, e.g., to values of 1 to $29 \%$ observed off Perpignan, France, during the ECOMARGE Programme by Monaco et al. 1990) could be explained by taking into account (1) the high turnover rate of nanophytoplankton (P. Dauby, M. Soullard \& J.-M. Bouquegneau unpubl.), mainly represented by coccolithophorids and silicoflagellates which are frequently observed on SEM pictures; (2) the importance of calcareous test fraction (rissoid mollusks, bryozoa, echinoids and benthic forams) in the seagrass bed upper sediment (Burhenne 1981, Poulicek \& Poppe 1981); (3) the importance, at least from mid-summer to early winter, of the colonies of incrusting calcareous red algae (Melobesieae) which epiphytize the Posidonia oceanica seagrass blades.

When comparing the TIC contents of matter collected in sequential traps with that in integrators (Table 2), significant discrepancies appear. Averaged values of TIC of matter collected in the sequential traps (SST or $\mathrm{SST}^{*}$ ) are systematically lower than those of matter from the integrators (IST or IST *). The mean inorganic enrichment in the latter is respectively +37 and
$+51 \%$, averaged over the year. We suggest that this enrichment can be attributed to the enhancement of microbial degradation in the integrators, the 'collecting' period of which lasted about 3 mo at each deployment. It also demonstrates that the poisoning of collection flasks has a time-limited effect, as suggested by Knauer et al. (1979).

$$
\text { Organic } \mathrm{C}: \mathrm{N} \text { ratios }-\delta^{13} \mathrm{C}_{\mathrm{OC}}
$$

The annual variations of the $\mathrm{C} / \mathrm{N}$ atomic ratio in the total trapped mater (SST samples), the 'resuspended' matter (SST' samples), and the 'sinking' matter, com-

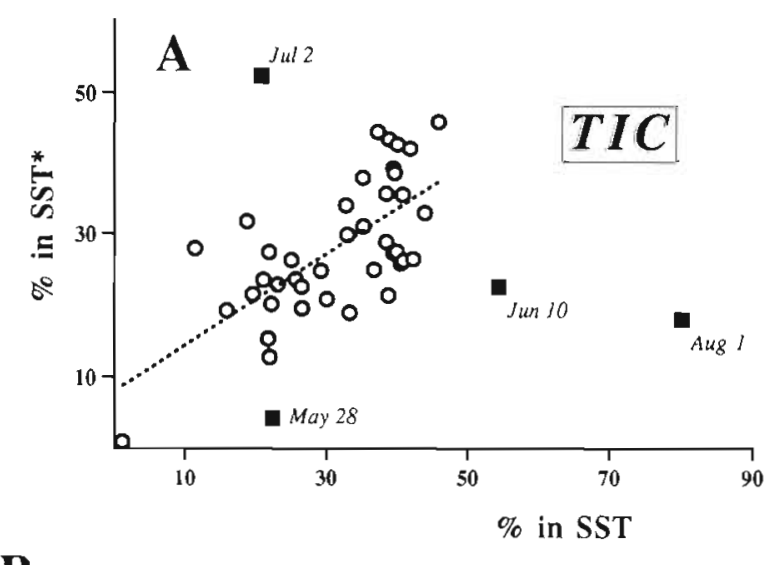

B

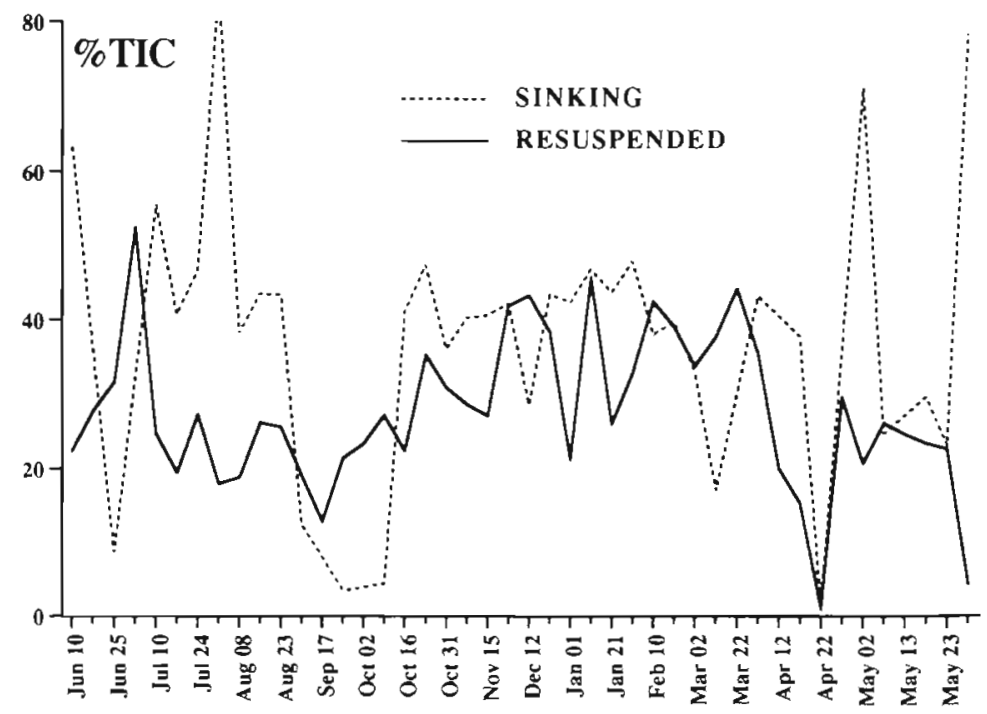

Fig. 6. (A) Comparison between total inorganic carbon content (TIC) of matter trapped respectively in SST and SST ${ }^{*}$ Data from the whole year cycle; suspicious values are noted (ロ) see 'Results and discussion'; regression was plotted from (O) values. (B) Annual variations in the total inorganic carbon content of 'sinking' and 'resuspended' matter trapped in the Bay of Calvi 

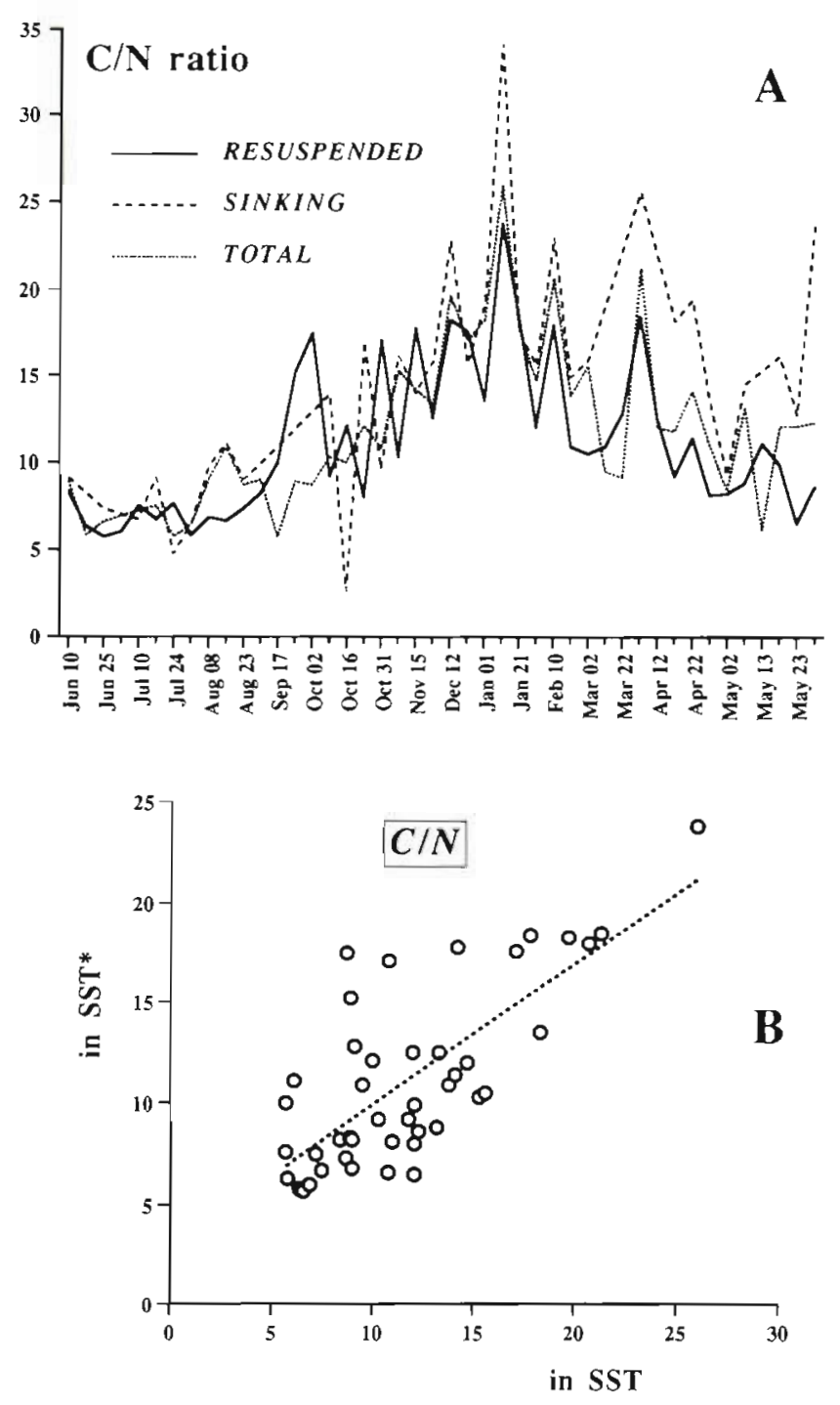

Fig. 7. (A) Annual variations in the $\mathrm{C} / \mathrm{N}$ ratio of 'sinking', 'resuspended' and total matter trapped in the Bay of Calvi. (B) Comparison between $\mathrm{C} / \mathrm{N}$ ratio of matter trapped respectively in SST and SST ${ }^{*}$ Data from a complete annual cycle

puted using an equation similar to $\mathrm{Eq}$. (2), is shown in Fig. $7 \mathrm{~A}$.

$\mathrm{C} / \mathrm{N}_{\mathrm{Sink}}=\left[\mathrm{C} / \mathrm{N}_{\mathrm{SST}}-\frac{\mathrm{C} / \mathrm{N}_{\mathrm{SST}} \cdot \times M_{\mathrm{SST}} \cdot M_{\mathrm{SST}}}{M_{\mathrm{SST}}-M_{\mathrm{SST}} \cdot}\right.$

The 3 kinds of matter follow the same evolution pattern, with a summer minimum ( $\mathrm{C} / \mathrm{N}$ of about 7 ) and a winter maximum (mean $\mathrm{C} / \mathrm{N}$ of about 16). Summer values are close to the classical Redfield ratio of 6.6 for living phytoplankton and to other published $\mathrm{C} / \mathrm{N}$ values of Mediterranean POM (particulate organic matter) (Copin-Montegut \& Copin-Montegut 1983, Gadel et al. 1990), which is not surprising as 'sinking' matter prevails
Table 2. Comparisons between TIC contents (\%, up) and $\mathrm{C} / \mathrm{N}$ ratios (down) of the material trapped during the 4 deployments of the Sequential Sediment Trap in the Bay of Calvi. $\mathrm{Av}$. SST and Av. SST ${ }^{*}$ are the averaged values for the 11 sequential samples of each array (respectively 'open' and 'capped' traps); IST and IST' are the corresponding values for the integrator samples

\begin{tabular}{|lcccc|}
\hline Array & Av. SST & IST & Av. SST & IST \\
\hline TIC & & & & \\
Jun 6-Aug 26 & 36.8 & 56.4 & 26.8 & 45.8 \\
Sep 5-Nov 25 & 29.4 & 44.6 & 26.4 & 45.1 \\
Dec 7-Mar 27 & 39.4 & 45.4 & 36.8 & 45.6 \\
Apr 3-May 30 & 24.7 & 32.2 & 20.3 & 30.2 \\
Year average & 32.6 & 44.7 & 27.6 & 41.7 \\
C/N & & & & \\
Jun 6-Aug 26 & 7.6 & & 6.8 & \\
Sep 5-Nov 25 & 10.8 & & 12.5 & \\
Dec 7-Mar 27 & 16.6 & 22.2 & 15.2 & 13.1 \\
Apr 3-May 30 & 12.2 & 13.8 & 10.3 & 11.8 \\
Year average & 11.8 & 18.0 & 11.2 & 12.5 \\
\hline
\end{tabular}

in trap samples during this period. Winter values suggest the importance of resuspended organic materials among which Posidonia-derived detritus is likely to dominate. The $\mathrm{C} / \mathrm{N}$ ratio of living $P$, oceanica leaves ranges from 23 to 40 (Romero et al. 1992, Gobert et al. unpubl.) and from 71 to 81 in dead leaves from litter (Romero et al. 1992); in seagrass epiphytes, the ratio ranges from 10 to 35 , according to season (Gobert et al. unpubl.). The importance of 'resuspended' matter becomes apparent when comparing the trapped matter mass and its $\mathrm{C} / \mathrm{N}$ ratio (Fig. 8A). In fact, both parameters appear closely related: $\mathrm{C} / \mathrm{N}=5.3 \log _{10}($ Mass $)+12.7(\mathrm{r}=0.71, \mathrm{p}=0.0001, \mathrm{SST}$ samples, mass in $\mathrm{g} \mathrm{m}^{-2} \mathrm{~d}^{-1}$ ). This suggests that increases in the amount of material in the sediment traps are mainly due to increasing resuspension of benthic material and that phytoplankton play only a minor role in the bulk flux of material collected close to the bottom.

Plotting $\mathrm{C} / \mathrm{N}$ ratios of $\mathrm{SST}^{*}$ against $\mathrm{SST}$ matter (Fig. 7B) shows, as for TIC contents, that a correlation $(r=0.74, p=0.0001)$ exists between the 2 data sets. The slope of the regression $(0.70)$ should indicate that SST * samples are, on the average, relatively $\mathrm{N}$-enriched compared to 'open' SST samples $(+35 \%)$. However, as was also observed for TIC contents, there are discrepancies between the average $\mathrm{C} / \mathrm{N}$ ratio of the samples collected by sequential traps and that of samples trapped by the integrators (Table 2 ). $\mathrm{C} / \mathrm{N}$ ratios are, on the average, 25 and $12 \%$ greater respectively in IST and IST', suggesting a corresponding $\mathrm{N}$ depletion. This depletion is most likely due to microbial degradation (detrital matter is usually $\mathrm{C}$-enriched), and corroborates observations made for TIC. A similar trend between \% TIC and $\mathrm{C} / \mathrm{N}$ data appears when plotting both parameters, one against the other (Fig. 8B). Dis- 

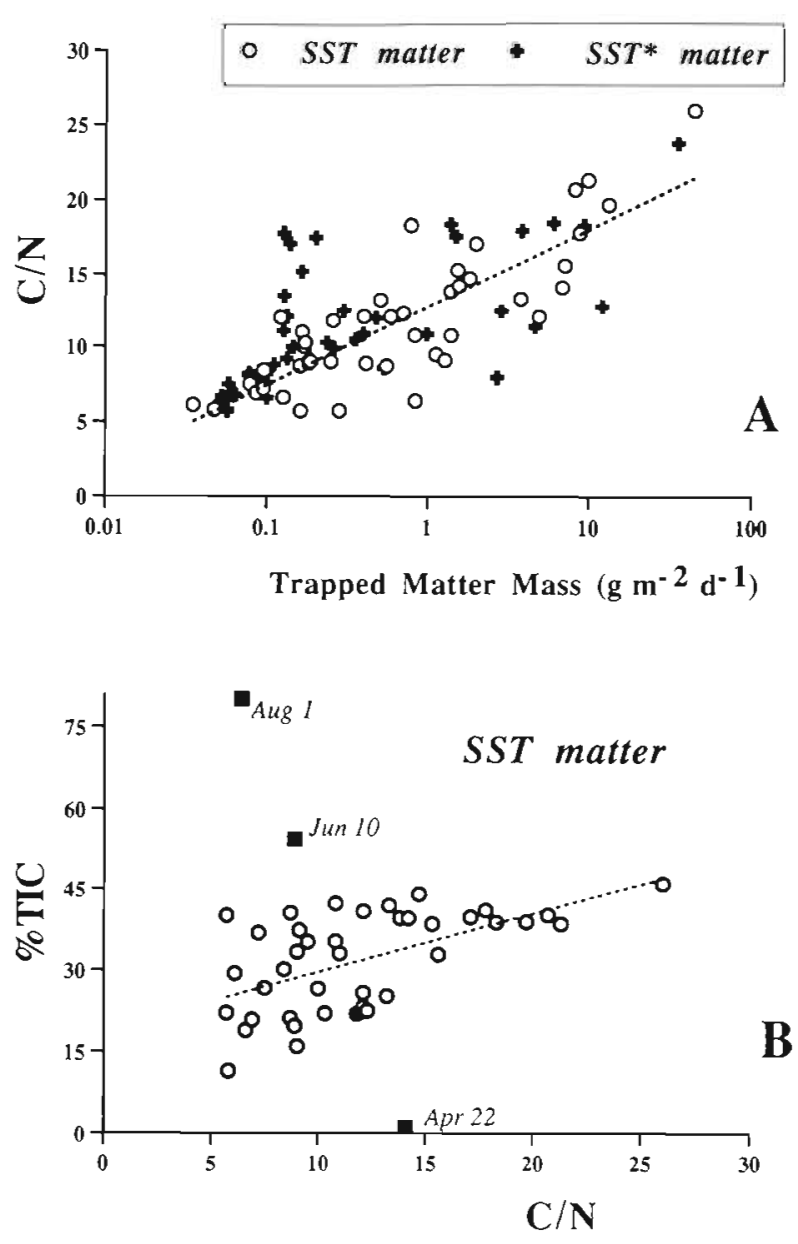

Fig. 8. (A) C/N ratio of SST (0) and SST ( $^{*}(\boldsymbol{t})$ samples as a function of the amount of trapped material. (B) Relationship between total inorganic carbon content (\% TIC) and C/N ratio of matter trapped in SST. Data from a complete annual cycle; suspicious values are noted $(\square)$; regression was plotted from (0) values

counting 3 out-of-range values, TIC content appears to increase along with the $\mathrm{C} / \mathrm{N}$ ratio (slope of 1.1 , with $\mathrm{TIC}$ in \%), with high values of both parameters corresponding to samples where 'resuspended' matter dominates. Two (June 10, August 1) of the 3 discarded values correspond with anomalous values also observed for $\mathrm{TIC}_{\mathrm{SST}} \cdot / \mathrm{TIC}_{\mathrm{SST}}$ ratios (Fig. $6 \mathrm{~A}$ ) but do not seem correlated to any peculiar local event.

The analysis of stable carbon isotope ratios in the trapped organic matter (Fig. 9) reveals maximum $\delta^{13} \mathrm{C}$ values (i.e. less negative, ${ }^{13} \mathrm{C}$-enriched) during winter months $(-13 /-14 \%)$, and minimal values in April and May $(-18 \%)$. The difference of about $5 \%$ between both seasons can be attributed to differences in the relative proportions of 'sinking' and 'resuspended' matter which is isotopically tagged. Sinking carbon is mainly derived from phytoplankton, for which $\delta^{13} \mathrm{C}$ ranges from -20 to $-23 \%$ at Calvi, according to season (Dauby

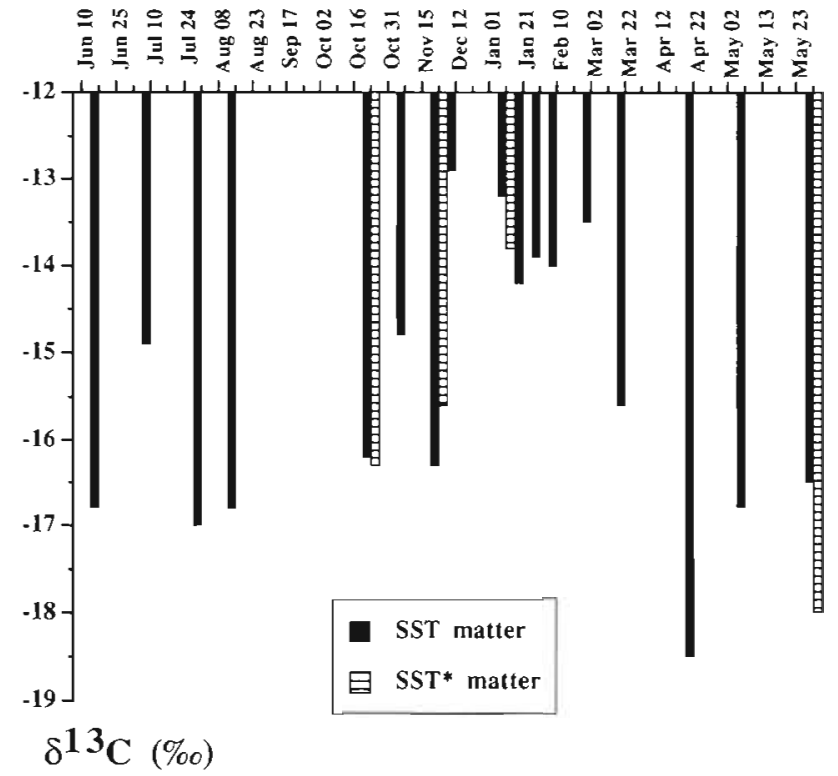

Fig. 9. Annual variations in the $\delta^{13} \mathrm{C}$ of the organic matter collected in sequential sediment traps in the Bay of Calvi

et al. 1990). These values are in good agreement with those published by Fontugne \& Duplessy (1981) for temperate water phytoplankton and by Faganeli et al. (1994) and Rau et al. (1990) for Mediterranean POM, the latter finding an inverse relationship between particle size and $\delta^{13} \mathrm{C}$. The pool of resuspended organic carbon mainly consists of detritus among which decaying pieces of Posidonia oceanica, by far the predominant primary producer in terms of biomass, would play a major role. The leaves of this seagrass detach mainly during the August to December period (Pergent \& Pergent-Martini 1990) and have $\delta^{13} \mathrm{C}$ values ranging from -9 to $-14 \%$, according to depth (Cooper \& DeNiro 1989, Dauby 1989). On the other hand, the sedimentary organic carbon of the Calvi seagrass meadow (which should correspond to 'average trapped matter') has a mean $\delta^{13} \mathrm{C}$ of about $-17 \%$ (Dauby 1989), which is intermediate between ${ }^{13} \mathrm{C} /{ }^{12} \mathrm{C}$ ratios of both planktonic and benthic sources. There is no significant riverine input that could interfere with the observed $\delta^{13} \mathrm{C}$ sedimentary values (Dauby 1989, 1994).

When correlating measured $\delta^{13} \mathrm{C}$ values to either the mass flux of trapped material or to its organic $\mathrm{C} / \mathrm{N}$ content (see Fig. 10), it appears that the ${ }^{13} \mathrm{C} /{ }^{12} \mathrm{C}$ ratio tends to increase with both parameters. This is not surprising, as heavy samples have a large proportion of 'resuspended' matter, which is highly loaded with Cand ${ }^{13} \mathrm{C}$-enriched benthic detritus. The covariance of $\delta^{13} \mathrm{C}$ with the $\mathrm{C} / \mathrm{N}$ ratio also suggests that the stable carbon isotope compositions of Calvi samples result mainly from mixing of ${ }^{13} \mathrm{C}$-depleted planktonic matter with the ${ }^{13} \mathrm{C}$-rich benthos. An inverse conclusion was 


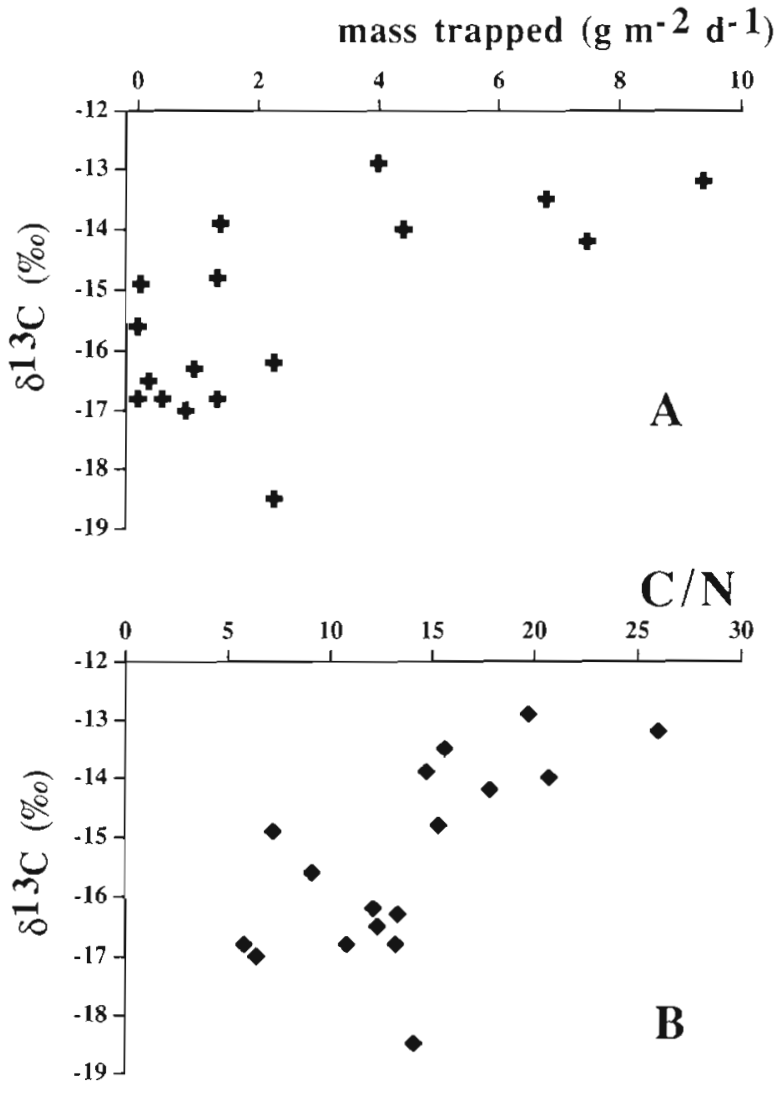

Fig. 10. Variations in the $\delta^{13} \mathrm{C}$ of matter trapped in SST as a function of the amount of $(A)$ collected matter and $(B)$ its C/N ratio

drawn e.g. by Hedges et al. (1988a) for material trapped in the Dabob Bay (Washington, USA) water column, where the importance of the planktonic matter masked the influence of allochthonous inputs.

\section{Particle SEM observations}

Photomicrographs obtained by SEM reveal seasonal trends in particle composition, as well as differences between SST and SST ' material. 'Closed' SST' sam. ples appeared to contain much less plankton-derived particles than 'open' SST samples, which is encouraging as the former were devised to collect mainly resuspended matter They, however, evidently trap some particles from the water column (e.g. see Fig 14) either because of horizontal advective currents or through mobilization of material recently settled onto the bed surface.

From May to the beginning of autumn, discrete particles are sparse on the sample filters. Planktonic material is dominated by silicoflagellates (Dictyocha sp.; Fig. 11) accompanied by some diatoms and dinoflagel- lates. Matter trapped by SST ${ }^{*}$ consists mainly of very fine organic debris and small inorganic grains (Fig. 12).

During autumn and winter, with the occurrence of storms, sample bulk drastically increases due mainly to resuspension processes. SEM reveals miscellaneous living or detrital particles in a wide range of sizes, e.g. benthic diatoms and foraminifers (Fig. 13), pieces of tests (e.g small mollusks, echinid spines, sponge spicules), crustacean shells, unidentifiable organic bodies, various sand grains and microcrystals; nevertheless, the most important particles (in term of mass) are plant debris derived from seaweeds - macroalgae or epiphytes - or seagrasses (Figs. 14 to 16). Such Posidonia oceanica debris is observed at various decay stages, from almost entire leaf pieces to fibres, often still bear incrusting calcareous bodies (Melobesieae, Fig. 15).

From mid winter to April, plankton-derived particles became markedly more common, especially in the SST samples. They mainly consisted of diatoms and, to a lesser extent, of dinoflagellates (Fig. 17). During this period, some zooplankters (mainly tintinnids and small copepods, Fig. 18) were encountered, but these never constituted a significant fraction of sample bulk.

SEM observations closely corroborate the results of the different chemical analyses, i.e. the preponderance of benthic plant-derived matter during severe meteorological conditions which enhance resuspension processes and the importance of water column material during planktonic blooms.

\section{CONCLUSIONS}

Despite that it must be borne in mind that the present study is only applicable to the model of the Bay of Calvi, Corsica, and can under no circumstances be simply transposed to other Posidonia oceanica beds (wherein hydrodynamic or hydrological conditions differ), this trap deployment experiment yielded considerable data about the fluxes of material above a seagrass bed in a coastal oligotrophic area. The total measured flux of matter entering the traps over a complete annual cycle was about $1.3 \mathrm{~kg} \mathrm{~m}^{-2}$, which corresponds to a mean daily flux of $3.7 \mathrm{~g} \mathrm{~m}^{-2}$. These values are in good agreement with other published data (reviewed by Wassmann 1983), but are quite low compared with those measured, e.g., by Buscail et al. (1990) and Monaco et al. (1990) on the western French Mediterranean continental shelf (26 to $110 \mathrm{~g} \mathrm{~m}^{-2} \mathrm{~d}^{-1}$ ), but the latter were influenced by land-derived inputs from the River Têt prodelta. In the Bay of Calvi, the only terrigenous inputs consist of eolian and rainfalldriven material which is negligible compared with the bulk of matter reaching the seafloor. This matter is 

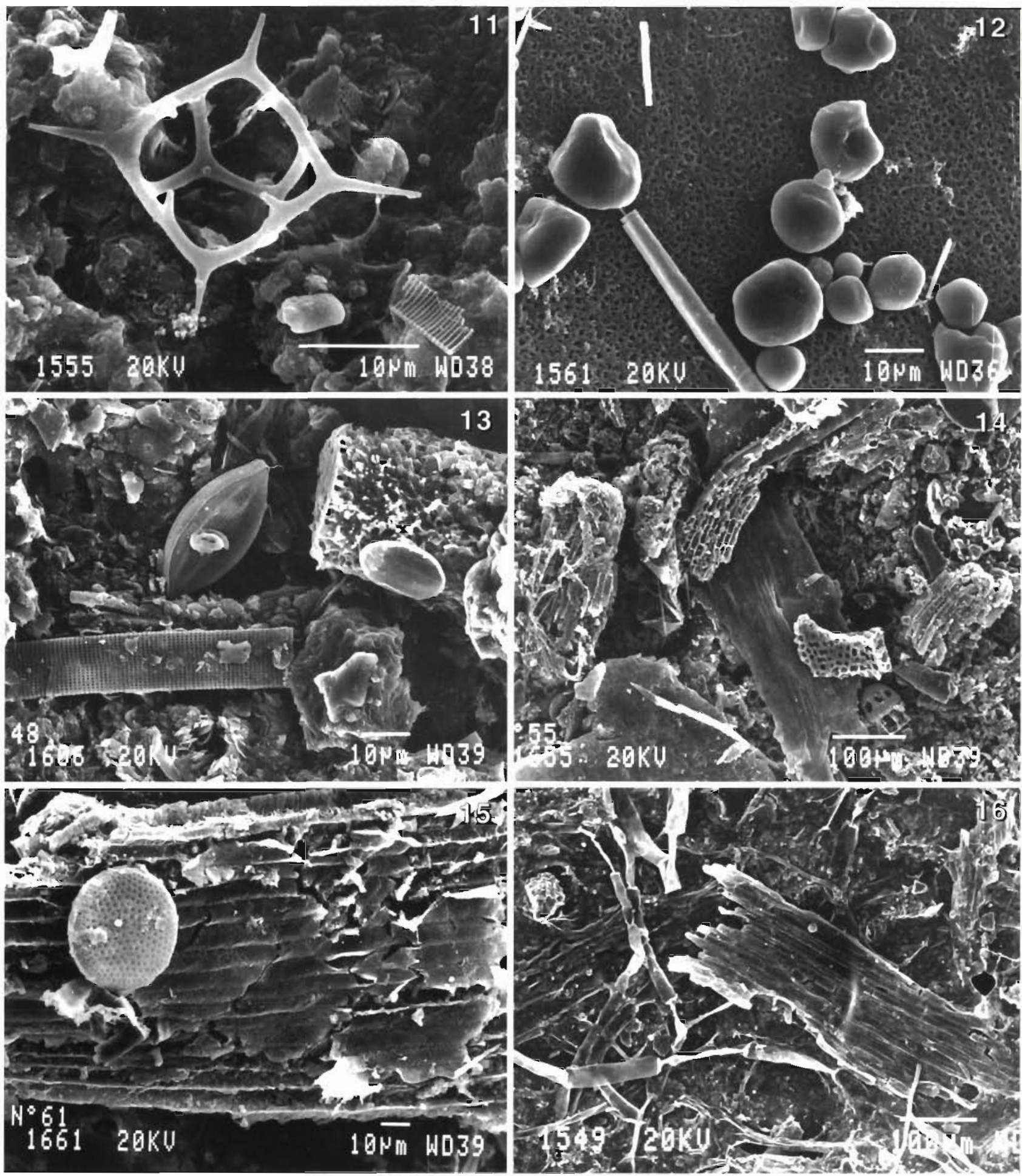

Fig. 11. SST sample, May 30, 1991. Miscellaneous organic debris and silicoflagellate test (Dictyocha fibula). Fig. 12. SST' sample, June 26, 1990. Sand grains and unidentified inorganic bodies. Fig. 13. IST* sample, August to November 1990 . Note the numerous tests of benthic organisms: foraminifera (Elphidium), diatoms (Navicula and other genera) and unidentified forms. Fig. 14. SST sample, February 15, 1991. Different bottom-originated debris, among which are several pieces of Posidonia oceanica Ieaves. Note the presence of a planktonic tintinnid (Dictyocysta). Fig. 15. SST sample, December 17, 1990. Detail of a P. oceanica leaf debris with an attached calcareous Melobesieae (Myrionema orbiculare) and remains of other epiphytes. Fig. 16. IST' sample, August to November 1990. Same as Fig. 14, but with pieces of brown branched algae 

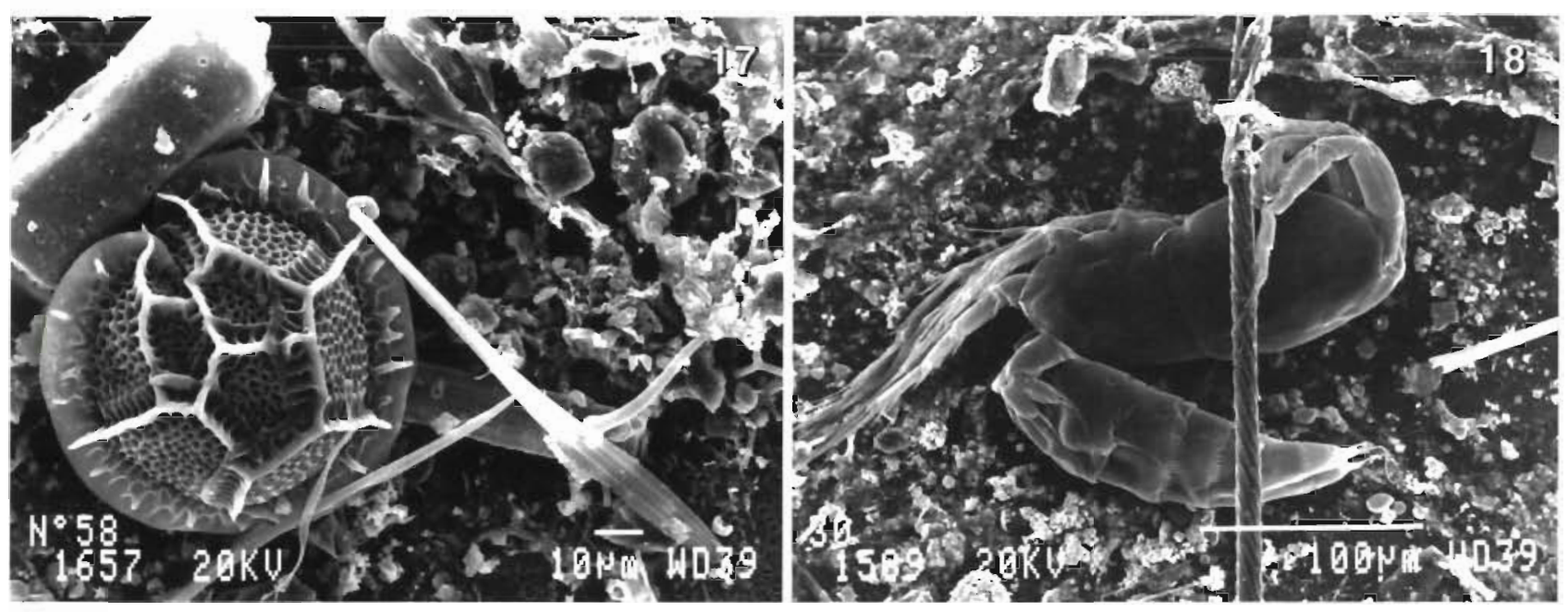

Fig. 17. SST sample, March 17, 1991. Detail of some encountered phytoplankton organisms: diatoms (e.g. Nitzschia), dinoflagellates (Gonyaulax?), and silicoflagellates (Dictyocha). Fig. 18. SST sample, April 29, 1991. Larval instars of 2 copepods (copepodid of Clausocalanus and nauplius of Microsetella) among various organic and inorganic bodies

almost entirely autochthonous, derived from local benthic and pelagic production.

Calculated yearly flux of settling suspended particulate matter is about $420 \mathrm{~g} \mathrm{~m}^{-2}$, which corresponds to a mean daily flux of $1.2 \mathrm{~g} \mathrm{~m}^{-2}$. These values are of the same order of magnitude as those presented by Monaco et al. (1990) for traps deployed in the photic zone of a relatively similar oceanic area, the LacazeDuthiers Canyon, Gulf of Lions, France. Assuming a mean POC/total trapped mass ratio of $10 \%$ (several authors in Wassmann 1983) and a mean local planktonic primary production estimate of $400 \mathrm{~g} \mathrm{C} \mathrm{m}^{-2} \mathrm{yr}^{-1}$ (Licot 1985, Velimirov \& Walenta-Simon 1992), our data suggest that about $10 \%$ of the matter produced in the pelagic zone should sink and reach the bottom in the shallow Bay waters. This value is similar to those observed in other neritic areas (Bedford Basin, 15\%: Hargrave \& Tagushi 1978; Lindåspollene, $19 \%$ : Wassmann 1983; Kingston, Jamaica, 15\%: Hopcroft et al. 1990 ) and corroborates the high grazing pressure suffered by phytoplankton in Calvi waters (Dauby 1985).

As could be predicted from the mooring position of the traps, resuspended material constituted a large

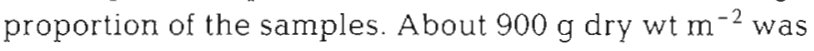
sampled over the year, which represented a mean daily increment of $2.5 \mathrm{~g} \mathrm{~m}^{-2}$ These values are quite high, when it is taken into account that terrestrial inputs are insignificant. Nevertheless, the amount of light and easily mobilized matter lying on the seafloor is considerable within the seagrass bed. The mean annual production of Posidonia oceanica blades is $600 \mathrm{~g} \mathrm{~m}^{-2}$ (Bay 1984), and plant epiphytes contribute another $200 \mathrm{~g} \mathrm{~m}^{-2}$ (Dauby et al. unpubl.). It is estimated that $70 \%$ of the material from these sources
(Pergent et al. 1994) becomes incorporated in the bed litter. This litter is partly exported and partly slowly degradated (decay rate of $-0.09 \mathrm{yr}^{-1}$; Romero et al. 1992), but the major fraction remains in the upper sediment layer and is thus easily remobilized. High concentrations of suspended material observed while scuba diving over the seagrass bed during winter storms clearly illustrate the ease with which resuspension processes affect the Posidonia-derived detritus. This material clearly forms the bulk of the resuspended fraction collected in the traps; it is obvious in SEM photomicrographs, and both $\mathrm{C} / \mathrm{N}$ and ${ }^{13} \mathrm{C} /{ }^{12} \mathrm{C}$ ratios confirm this conclusion.

Both pelagic- and benthos-derived trapped matter show an annual variation pattern. The former prevails during plankton blooms, and the latter shows maxima associated with northerly wind stresses. Variations in the relative contribution of these 2 organic matter sources induce concurrent changes in the $\mathrm{C} / \mathrm{N}$ ratio and $\delta^{13} \mathrm{C}$ of the trapped organic fraction, the benthic matter being significantly ${ }^{13} \mathrm{C}$-enriched and $\mathrm{N}$-depleted.

The trap system used here allowed the material to be fractionated according to its origin (plankton + seston versus benthos) and appeared to be a reasonable method for the assessment of sedimentary processes occurring in a coastal environment where current velocities are low $\left(<10 \mathrm{~cm} \mathrm{~s}^{-1}\right)$. Being aware of some particle flux measurement problems inherent in such shallow areas (storm effects, disturbances due to the benthic macrofauna or to diver's activity), we believe that sediment traps can provide reliable information about the amount and the composition of the matter that reaches the sea floor and about the processes which influence its biogeochemical cycling 
Acknowledgements. The authors thank D. Bay and the whole crew of the Oceanographic Station STARESO (Calvi, Corsica) for their help during sampling campaigns. Wind speed and direction data were partly provided by the meteorological staff of the Calvi Airport. F. Mosora is acknowledged for the facilities she offered in the realization of IR-MS measurements. Ch. Breeur kindly printed the photomicrographs. $G$. Pergent and 2 anonymous reviewers are thanked for their valuable criticisms of the manuscript. This work was funded by the European Union (contract MAST-CT90-0019-C). M. Frankignoulle is Research Associate at the Belgian National Fund for Scientific Research (FNRS).

\section{LITERATURE CITED}

Bale AJ (1995) Sediment trap performance in tidal waters: a field evaluation. Cont Shelf Res (in press)

Bay D (1984) A field study of the growth dynamics and productivity of Posidonia oceanica (L.) Delile in Calvi Bay, Corsica. Aquat Bot 20:43-64

Boudouresque CF, Thommeret J, Thommeret Y (1980) Sur la découverte d'un bioconcrétionnement fossile intercalé dans l'herbier à Posidonia oceanica dans la baie de Calvi (Corse). Journ Ét Systém Biogéogr médit, Comm int Expl Sci Mer Médit, Cagliari, p 139-142

Brohée M, Goffart A, Frankignoulle M, Henri V, Mouchet $A_{\text {, }}$ Hecq JH (1989) Variations printanières des communautés planctoniques en baie de Calvi (Corse) en relation avec les contraintes physiques locales. Cah Biol mar 30:321-328

Buesseler KO (1991) Do upper-ocean sediment traps provide an accurate record of particle flux? Nature 353:420-423

Burhenne M (1981) Facies sédimentaire du précontinent calvais, note introductive. Bull Soc $R$ Sci Liège 50:387-404

Buscail R, Pocklington R, Daumas R, Guidi L (1990) Fluxes and budget of organic matter in the benthic boundary layer over the northwestern Mediterranean margin. Cont Shelf Res 10:1089-1122

Caye G (1982) Etude sur la croissance de la Posidonie, Posidonia oceanica (L.) Delile: formation des feuilles et croissance des tiges au cours d'une année. Téthys 10:229-235

Cooper LW, DeNiro MJ (1989) Stable carbon isotope variability in the seagrass Posidonia oceanica: evidence for light intensity effects. Mar Ecol Prog Ser 50:225-229

Copin-Montegut C, Copin-Montegut G (1983) Stoichiometry of carbon, nitrogen, and phosphorus in marine particulate matter. Deep Sea Res 30:31-46

Dauby $\mathrm{P}$ (1985) Dynamique et productivité de l'écosystème planctonique du Golfe de Calvi-Corse. Doct thesis, Univ Liège

Dauby P (1989) The stable carbon isotope ratios in benthic food webs of the Gulf of Calvi, Corsica. Cont Shelf Res 9:181-195

Dauby P (1995) A $\delta^{13} \mathrm{C}$ study of the feeding habits of Mediterranean Leptomysis species (Crustacea: Mysidacea) PSZN I: Mar Ecol 16: in press

Dauby P, Mosora F, Vertez M (1990) A yearly study of ${ }^{13} \mathrm{C} /{ }^{12} \mathrm{C}$ isotopic ratio variations in the Calvi's Bay plankton. Rapp P-v Réun Comm int Explor scient Mer Médit 32:202-203

Eppley RW, Renger EH, Betzer PR (1983) The residence time of particulate organic carbon in the surface layer of the ocean. Deep Sea Res 30:311-323

Faganeli J, Pezdic J, Ogorelec B, Misic M, Najdek M (1994) The origin of sedimentary organic matter in the Adriatic. Cont Shelf Res 14:365-384

Fontugne MR, Duplessy JC (1981) Organic carbon isotopic fractionation by marine plankton in the temperature range -1 to $31^{\circ} \mathrm{C}$. Oceanol Acta $4: 85-90$
Frankignoulle M, Gattuso JP (1993) Air-sea $\mathrm{CO}_{2}$ exchange in coastal ecosystems. In: Wollast R, Mackenzie FT, Chou L (eds) Interactions of C, N, P and S biogeochemical cycles and global change. Springer-Verlag, Berlin, NATO ASI Ser 14:233-248

Gadel F, Puigbo A, Alcañiz JM, Charrières B, Serve L (1990) Tracers and constituents indicating the nature of organic fluxes, their origin and the effect of environmental conditions. Cont Shelf Res 10:1039-1062

Gardner WD (1985) The effect of tilt on sediment trap efficiency. Deep Sea Res 32:349-361

Gardner WD, Richardson MJ, Hinga KR, Biscaye PE (1983) Resuspension measured with sediment traps in a high energy environment. Earth planet Sci Lett 66:262-278

Harbison GR, Gilmer RW (1986) Effects of animal behavior on sediment trap collections: implications for the calculation of aragonite fluxes. Deep Sea Res 33:1017-1024

Hargrave BT, Burns NM (1979) Assessment of sediment trap collection efficiency. Limnol Oceanogr 24:1124-1135

Hargrave BT, Tagushi S (1978) Origin of deposited material sedimented in a marine bay. J Fish Res Bd Can 35: $1604-1613$

Hedges JI, Clark WA, Cowie GL (1988a) Organic matter sources to the water column and superficial sediments of a marine bay. Limnol Oceanogr 33:1116-1136

Hedges JI, Clark WA, Cowie GL (1988b) Fluxes and reactivities of organic matter in a coastal marine bay. Limnol Oceanogr 33:1137-1152

Heussner S, Ratti C, Carbonne J (1990) The PPS3 time-series sediment trap and trap sample processing techniques used during the ECOMARGE experiment. Cont Shelf Res $10: 943-958$

Hopcroft RR, Roff JC, Berges JA (1990) Size-fractionated sedimentation in a tropical neritic ecosystem near Kingston. Jamaica. Cont Shelf Res 10:795-806

Knauer GA, Karl DM, Martin JH, Hunter CN (1984) In situ effects of selected preservatives on total carbon, nitrogen and metals collected in sediment traps. J mar Res 42 : 445-462

Knauer GA, Martin JH, Bruland KW (1979) Fluxes of particulate carbon, nitrogen, and phosphorus in the upper water column of the northeast Pacific. Deep Sea Res 26:97-108

Larkum AWD, McComb AJ, Shepherd SA (1989) Biology of seagrasses. Elsevier, Amsterdam

Lee C, Wakeham SG, Hedges JI (1988) The measurement of oceanic particle flux - are 'swimmers' a problem? Oceanography 1:34-36

Licot $M$ (1985) Etude écohydrodynamique du front liguroprovençal au large de la Corse: relations entre l'hydrodynamique, les paramètres physico-chimiques et la production primaire. Doct thesis, Univ Liège

McRoy CP, Helfferich C (1977) Seagrass ecosystems: a scientific perspective. Marcel Dekker, New York

Michaels AF, Silver MW, Gowing MM, Knauer GA (1990) Cryptic zooplankton 'swimmers' in upper ocean sediment traps. Deep Sea Res 37:1285-1296

Monaco A, Courp T, Heussner S, Carbonne J, Fowler SW, Deniaux B (1990) Seasonality and composition of particulate fluxes during ECOMARGE-I, western Gulf of Lions. Cont Shelf Res 10:959-987

Pergent G, Pergent-Martini C (1990) Some applications of lepidochronological analysis in the seagrass Posidonia oceanica. Botanica mar 33:299-310

Pergent $G$, Romero J, Pergent-Martini C, Mateo MA, Boudouresque CF (1994) Primary production, stocks and fluxes in the Mediterranean seagrass Posidonia oceanica. Mar Ecol Prog Ser 106:139-146 
Phillips RC, McRoy CP (1980) Handbook of seagrass biology. Garland STM Press, New York

Poulicek M, Poppe G (1981) Contribution des coquilles de mollusques à la constitution de la fraction organodétritique des sédiments marins (Corse, mer Méditerranée). Bull Soc R Sci Liège 50:519-542

Rau GH, Teyssié JL, Rassoulzadegan F, Fowler SW (1990) ${ }^{13} \mathrm{C} /{ }^{12} \mathrm{C}$ and ${ }^{15} \mathrm{~N} /{ }^{14} \mathrm{~N}$ variations among size-fractionated marine particles: implications for their origin and trophic relationships. Mar Ecol Prog Ser 59:33-38

Romero J, Pergent G, Pergent-Martini C, Mateo MA, Regnier $C$ (1992) The detritic compartment in a Posidonia oceanica meadow: litter features, decomposition rates and mineral stocks. PSZN I: Mar Ecol 13:69-83

Sherwood CR, Butman B, Cacchione DA, Drake DE, Gross TF, Sternberg RW, Wiberg PL, Williams AJ III (1994) Sediment-transport events on the northern California continental shelf during the 1990-1991 STRESS experiment.

This article was submitted to the editor
Cont Shelf Res 14:1063-1099

Smith SV (1981) Marine macrophytes as a global carbon sink Science 211:838-840

Soullard M, Bourge I, Fogel J, Lardinois D, Matthieu T, Veeschkens C, Bay D, Dauby P. Bouquegneau JM (1994) Evolution of the shoot density of the Posidonia seagrass bed of Calvi Bay (Corsica). Vie Milieu 44:199-201

Thommeret Y (1985) Activités scientifiques du laboratoire de radioactivité appliquée de 1960 à 1983. Bull Cent sci Monaco 1:1-78

Velimirov B, Walenta-Simon M (1992) Seasonal changes in specific growth rates, production and biomass of a bacterial community in the water column above a Mediterranean seagrass system. Mar Ecol Prog Ser 80:237-248

Wassmann P (1983) Sedimentation of organic and inorganic particulate material in Lindåspollene, a stratified, landlocked fjord in western Norway. Mar Ecol Prog Ser 13 $237-248$

Manuscript first received: October 6,1994

Revised version accepted: April 6, 1995 